\title{
DEMOCRACY AND CONSTITUTIONS
}

\section{Putting Citizens First}

As things stand, a commitment to weak democracy and strong constitutionalism ensures that a range of elite groups, actors, and institutions - political, economic, intellectual, and legal hold considerable sway over constitutional matters, leaving less room for the participation of ordinary people. With the continued primacy of liberal constitutionalism, constitutional law has come to represent and facilitate the centrality of judicial power and authority. In Democracy and Constitutions, Allan C. Hutchinson warns against this deference to a legal elite on questions of constitutional meaning. For Hutchinson, an over-reliance on constitutional law, and a lack of attention to democratic politics, keeps people from influencing the moral and political character of society; it saps civic energies and relegates ordinary people to the sidelines.

Engaging and provocative, Democracy and Constitutions charts a course away from the elitism of the present and toward a more democratic future, one that re-balances society's commitment to both democracy and constitutions. Advocating for a strong democracy and weak constitutionalism, this book places ordinary people at the institutional heart of government and politics, arguing that such a re-calibration is better for democracy and for society.

ALLAN C. HUTCHINSON is a distinguished research professor at the Osgoode Hall Law School, York University. 
(ii)

\section{UTP insights}

UTP Insights is an innovative collection of brief books offering accessible introductions to the ideas that shape our world. Each volume in the series focuses on a contemporary issue, offering a fresh perspective anchored in scholarship. Spanning a broad range of disciplines in the social sciences and humanities, the books in the UTP Insights series contribute to public discourse and debate and provide a valuable resource for instructors and students.

For a list of books published in the series, please see page 207. 


\section{DEMOCRACY AND CONSTITUTIONS}

Putting Citizens First

Allan C. Hutchinson 
(C) University of Toronto Press 2021

Toronto Buffalo London

utorontopress.com

Printed in the U.S.A

ISBN 978-1-4875-0792-3 (cloth) ISBN 978-1-4875-3723-4 (EPUB)

ISBN 978-1-4875-0793-0 (paper) ISBN 978-1-4875-3722-7 (PDF)

\section{Library and Archives Canada Cataloguing in Publication}

Title: Democracy and constitutions : putting citizens first / Allan C. Hutchinson.

Names: Hutchinson, Allan C., 1951- author.

Series: UTP insights.

Description: Series statement: UTP insights | Includes bibliographical references and index.

Identifiers: Canadiana (print) 20210157658 | Canadiana (ebook) 20210157798 | ISBN 9781487507930 (paper) | ISBN 9781487507923 (cloth) | ISBN 9781487537227 (PDF) | ISBN 9781487537234 (EPUB)

Subjects: LCSH: Constitutional law. | LCSH: Democracy.

Classification: LCC K3165.H88 2021 | DDC 342.02-dc23

The Book of Laughter and Forgetting by Milan Kundera. Copyright (C Milan Kundera, 1978, used by permission of The Wylie Agency (UK) Limited.

University of Toronto Press acknowledges the financial assistance to its publishing program of the Canada Council for the Arts and the Ontario Arts Council, an agency of the Government of Ontario. 
"The struggle of man against power is the struggle of memory against forgetting."

- Milan Kundera 